RJPSSs, Vol. XLVI No.1, June 2020 ISSN: (P)0048-7325 (e) 2454-7026 Impact Factor 7.821 (SJIF)

https://doi.org/10.31995/rjpsss.2020v46i01.11

\title{
Visual Evaluation of Khadi Fabric Dyed with ANTIBaCterial and Antifungal Natural Dye
}

\author{
Deepa Tyagi \\ Research Scholar \\ Dept. of Home Science \\ $M L \& J N K$ Girls College, \\ Saharanpur (U.P.) \\ Email: tyagi-deepatyagi205@gmail.com
}

\author{
Pankaj Chhabra \\ Associate Professor \\ Dept. of Home Science \\ $M L \& J N K$ Girls College, \\ Saharanpur (U.P.)
}

Reference to this paper

should be made as follows:

Received: 31.05 .2020

Approved: 07.07.2020

So we have to use the eco-friendly natural dye to reduce the textile industry pollution in the environment. In the present study evaluated the visual evaluation of Khadi fabric dyed with antibacterial and antifungal natural dye. In this study eight dye (Toon, Gular, Bargad, Jamun bark and Shisham, Mehndi, Guava, Ashok leaves) were selected to extract the dye. After extraction, the dye Khadi fabric was dyed with natural dye. Dye sample color properties were tested and then construct the garment (Hanky, Sameej, and Scarf) to test the visual evaluation of natural dyed Khadi fabric. 640 responses were used for the study. Naturally dyed Khadi fabrics sold the customer to check the visual evaluation. The questionnaires were used to collect data after using the Khadi dyed fabric. After collecting the data we analyzed the data and we found that result was good. Hypothesis was tested at 0.05 level of significance using the ' $t$ ' test. We found that all samples were accepted as a good quality of the dye. The ' $t$ ' test was significant at 0.05 level of significance. The dye sample was accepted by the customer for their different quality like texture, color, appearance, brightness, and smoothness.

Keywords:Natural dye, bark, leaves, Khadi fabric, Antibacterial activity, Antifungal activity, colorfastness, visual evaluation.

\section{DeepaTyagi \\ Pankaj Chhabra}

VISUAL EVALUATION OF KHADI

FABRIC DYED WITH

ANTIBACTERIAL AND ANTIFUNGAL NATURAL DYE

RJPSSs 2020, Vol. XLVI,

No. 1, pp. 93-103 Article No.11

Online available at: http://rjpsss.anubooks.com/ https://doi.org/10.31995/ rjpsss.2020v46i01.11 
VISUAL EVALUATION OF KHADI FABRIC DYED WITH ANTIBACTERIAL AND ANTIFUNGAL NATURAL DYE DeepaTyagi, Pankaj Chhabra

\section{Introduction}

Most plants have become the prominent and abundant sources of colorant which one can utilize for application of dye on textile products since ancients. ${ }^{1}$ Natural dyes were used only for coloring of textiles from ancient times until the nineteenth century. As the name suggests, natural dyes are derived from natural resources. Coloring materials obtained from natural resources of plant, animal, minerals, and microbial origins were used for the coloration of various textile materials. Different regions of the world had their own natural dyeing traditions utilizations the natural resource available in that region. Use of natural dyes started to decline after the invention of synthetic dyes and rapid industrialization of textile production resulted in the almost complete replacement of natural dyes by synthetic dyes on account of their easy availability in ready to apply from, the simple application process, consistency of shades, and better fastness properties. The tradition of using natural dyes could survive only in certain isolated pockets. ${ }^{2}$

Recent environmental awareness has again revived interest in natural dyes mainly in among environmentally conscious people. Natural dye is considered ecofriendly as these are renewable and biodegradable, are skin-friendly, and may also provide health benefits to the wearer. Natural dyes can be used for dyeing almost all types of natural fibers. ${ }^{3}$

In contrast, natural dyes are environmentally friendly, exhibit better biodegradability, and generally have higher compatibility with the environment than synthetic dyes. ${ }^{4}$ Recent resurgence in research and development on natural dye production and application is observed due to increasing popularity of more natural lifestyle based on naturally sustainable goods ${ }^{5}$. Natural dyes can be sorted into three categories: natural dyes obtained from plants for example indigo, those obtained from animals for example cochineal, and those obtained from minerals for example ocher. ${ }^{6}$ Natural dyes/colorants derived from flora and fauna are believed to be safe because of its non-toxic, non-carcinogenic, and biodegradable. ${ }^{7}$ In many of the world's developing countries, however, natural dyes can offer not only a rich and varied source of dyestuff but also the possibility of an income through sustainable harvest and sale of these dye plants. Many dyes are available from tree waste or can be easily grown in market gardens. ${ }^{8}$

The present research deals with the natural dye obtained from the bark (Toon, Gular, Bargad, and Jamun) and leaves (Shisham, Mehndi, Guava, and Ashok).

In the present work, the bark ((Toon, Gular, Bargad, and Jamun) and leaves (Shisham, Mehndi, Guava and Ashok) were used for the extraction of dye, dyeing of the selected fabrics at optimized conditions and evaluate the antimicrobial properties 
RJPSSs, Vol. XLVI No.1, June 2020 ISSN: (P)0048-7325 (e) 2454-7026 Impact Factor 7.821 (SJIF)

https://doi.org/10.31995/rjpsss.2020v46i01.11

of dye extract and the colorfastness of the dyed sample. After extraction, the dye Khadi fabric was dyed with natural dye. Dye sample color properties were tested and then construct the garment (Hanky, Sameej, and Scarf) to test the visual evaluation of natural dyed Khadi fabric and collect the data and analysis the visual evaluation of collected data.

\section{Materials And Methods}

\section{Materials}

\section{Source}

The bark ((Toon, Gular, Bargad, and Jamun) and leaves (Shisham, Mehndi, Guava, and Ashok) collected

\section{Experimental Methods}

\section{Dye Extraction}

The clean air-dried barks and leaves were chopped into small pieces and coarsely ground using an electric grinder. Aqueous medium was prepared in $300 \mathrm{ml}$ of water without using chemicals and maintained the $\mathrm{pH} 6$ separately $30 \mathrm{gm}$ of dyestuff was added and the dye was extracted for $90 \mathrm{~min}$. at $90 æ \% \mathrm{C}$ the solution was filtered.

\section{Test solutions of natural dye}

Test solution of a series of concentrations viz. 20,50,100,250,400 mg/ml were prepared by dissolving natural dye obtained from different leaves and barks in an aqueous medium.

\section{Antibacterial screening test}

Antifungal screening test

Collection of fabric for dyeing

Preparatory process of the fabric dyeing

Scouring (ECE phosphate detergent) was done to prepare the fabric for dyeing.

\section{Preparation of the final fabric}

Solution containing $0.5 \mathrm{ml}$ mild detergent per hundred $\mathrm{ml}$ of water was prepared and heated at $50 æ \% \mathrm{C}$ temperature. These fabrics were dipped into solution \& stirred gently for about 30 minutes. Then it was rinsed under tap water till free from trace of detergent.

\section{Optimization of time \& temperature for fabric dyeing}

A series of following experiments were conducted to determine the dying time and dyeing temperature:- 
VISUAL EVALUATION OF KHADI FABRIC DYED WITH ANTIBACTERIAL AND ANTIFUNGAL NATURAL DYE

DeepaTyagi, Pankaj Chhabra

\section{Dyeing time}

To optimize the dyeing time 3 options were considered i.e., 45, 60, 90 minutes then 90 minutes was found best results and this was selected for the study.

\section{Dyeing temperature}

To optimize the dyeing temperature 3 options were 45,60 , and 80 temperature than $80 æ \% \mathrm{C}$ temperature was found best results and this was selected for the study.

\section{Identification and naming of obtained colors}

Test the properties of Khadi fabric prior to dyeing (physical properties)

Measurement of color strength (K/S Value)

Test the properties (fastness) of dyed Khadi fabric

To construct the naturally dyed Khadi fabric garments and study for

customer acceptability

\section{Garment construction procedure}

The present study was taken up during the year 2018-2019.

\section{Selection of raw materials}

Khadi fabric was selected to prepare the garments (Hanky, Sameej, and Scarf).

\section{Collection of raw materials}

Khadi fabric was purchased from KHADI BHAWAN, Saharanpur.

\section{Equipment used}

For the development of clothing for dye many types of equipment used. There were sewing machines, pick machines and embroidery machines.

\section{Material used}

Some helping material like scissors, inch tape, thread reel, Milton chalk was used in the preparation of clothing. Embroidery has great importance in the beautification of the hanky. Pick and cotton laces were used for giving the final touch and embroidery to the hanky for embellishment.

\section{Sketching the garment}

Based on the skin touch fabric feature three garment (Hanky, Sameej, Scarf) sketching was prepared.

\section{Drafting the garment}

Garment drafting was prepared for construction of the garment. Drafting was an easy method to construct the garment. Drafting saves time and fabric.

\section{Construct (development) the garment}

Three different type of clothing was developed for dyeing in which Hanky, 
RJPSSs, Vol. XLVI No.1, June 2020 ISSN: (P)0048-7325 (e) 2454-7026 Impact Factor 7.821 (SJIF)

https://doi.org/10.31995/rjpsss.2020v46i01.11

Sameej, and Scarf were prepared with keeping in mind that the garment is used on the direct skin and after dye, the garment evaluates the skin allergic properties.

Dye the constructed Khadi fabric

After construct the garment, All garments were dyed with antibacterial and antifungal dye. Dye the garment than garment dried in air and ironed.

Dye the constructed Khadi fabric

Dye, pick, embroidery, and other construction expenses included in the cost of each garment and create the cost label.

\section{Sample sell procedure}

Selection of the study area

\section{Locate the study}

This study was conducted in Saharanpur and Haridwar. The two places were purposively selected to increase the awareness of antibacterial and antifungal dye. The researcher's accessibility and safety to the area were the other factors kept in mind while selecting the locale.

\section{Sampling Method}

\section{Sample Design}

In Haridwar and Saharanpur, 3 main garments for customers so purposive sampling was used in the study to collect the data from a group of Haridwar and Saharanpur city. Every group was helped in the collection of data. Address of the customer was collected from every group customer.

\section{Sample size}

Total of 640 sample sizes was taken for this study. Three types of samples (garment) were selected, these are as follow:- (a) Working persons (b) Non-Working persons (c) Shopkeepers (d) Teenagers groups (e) Fourth class (d) Bussiness group

\section{Tool used for data collection}

Observation cum questionnaire method and opinion schedule was used to collect data and information. A well-structured questionnaire was developed to collect the data related to the customer general information, visual evaluation, and assessment of the Khadi fabric dyed with anti-bacterial and anti-fungal dye.

\section{Statistical Analysis}

\section{Collection of data}

We collect the data to sell the sample to the customer and take the information related to the customer and dyed antibacterial and antifungal dye.

\section{Tabulation of data}


VISUAL EVALUATION OF KHADI FABRIC DYED WITH ANTIBACTERIAL AND ANTIFUNGAL NATURAL DYE

DeepaTyagi, Pankaj Chhabra

Tabulate the data basis of questionnaire information which takes the customer to sell the sample to the customer.

\section{Interpretation of data}

Interpretation of the data basis of questionnaire information which takes the customer to sell the sample to the customer.

\section{Results and Discussion}

The results obtained from the present investigation as well as relevant discussion have been summarized under the following heads:-

Visual evaluation of Khadi fabric dyed with Toon antibacterial and antifungal natural dye

\begin{tabular}{|c|c|c|c|c|c|c|c|}
\hline $\mathrm{Sr}$. & \multicolumn{7}{|c|}{ Bargad dyed Khadi fabric } \\
\hline 1. & $\begin{array}{c}\text { Statistical } \\
\text { value point }\end{array}$ & Texture & Colour & Appearance & Brightness & Smoothness & Overall \\
\hline 2. & Total Marks & 786 & 754 & 761 & 472 & 790 & 3,563 \\
\hline 3. & Average & 9.82 & 9.42 & 9.51 & 5.9 & 9.87 & 44.53 \\
\hline 4. & Percentage & 98.25 & 94.25 & 95.12 & 59 & 98.75 & 89.07 \\
\hline 5. & M ean & \multicolumn{6}{|c|}{712.6} \\
\hline 6. & S.D. & \multicolumn{6}{|c|}{135.39} \\
\hline 7. & ' $\mathrm{t}$ ' & \multicolumn{6}{|c|}{0.79} \\
\hline 8. & $\mathrm{df}$ & \multicolumn{6}{|c|}{4} \\
\hline 9. & $\mathrm{p}$ & \multicolumn{6}{|c|}{$<0.05$} \\
\hline
\end{tabular}

Above table explain that Toon dyed Khadi fabric got good marks in texture aspect comparison of others as aspect and ' $\mathrm{t}$ ' value are significant at $5 \%(\mathrm{p}<0.05)$ level.

\section{Visual evaluation of Khadi fabric dyed with Gular antibacterial and antifungal natural dye}

\begin{tabular}{|c|c|c|c|c|c|c|c|}
\hline $\begin{array}{l}\text { Sr. } \\
\text { no. }\end{array}$ & \multicolumn{7}{|c|}{ Gular dyed Khadi fabric } \\
\hline 1. & $\begin{array}{c}\text { Statistical } \\
\text { value point }\end{array}$ & Tex ture & Colour & Appearance & Brightness & Smoothness & Overall \\
\hline 2. & Tota $1 \mathrm{M}$ arks & 793 & 754 & 761 & 444 & 773 & 3,525 \\
\hline 3. & Average & 9.91 & 9.42 & 9.51 & 5.55 & 9.66 & 44.06 \\
\hline 4. & Percentage & 99.12 & 94.25 & 95.12 & 55.50 & 96.62 & 88.12 \\
\hline 5. & Mean & \multicolumn{6}{|c|}{705} \\
\hline 6. & S.D. & \multicolumn{6}{|c|}{146.65} \\
\hline 7. & 't' & \multicolumn{6}{|c|}{0.74} \\
\hline 8. & $\mathrm{df}$ & \multicolumn{6}{|c|}{4} \\
\hline 9. & $\mathrm{p}$ & \multicolumn{6}{|c|}{$<0.05$} \\
\hline
\end{tabular}

Above table explain that Gular dyed Khadi fabric got good marks in texture aspect comparison of others as aspect and ' $\mathrm{t}$ ' value are significant at $5 \%(\mathrm{p}<0.05)$ level. 
RJPSSs, Vol. XLVI No.1, June 2020 ISSN: (P)0048-7325 (e) 2454-7026 Impact Factor 7.821 (SJIF)

https://doi.org/10.31995/rjpsss.2020v46i01.11

Visual evaluation of Khadi fabric dyed with Bargad antibacterial and antifungal natural dye

\begin{tabular}{|c|c|c|c|c|c|c|c|}
\hline $\begin{array}{c}\text { Sr. } \\
\text { no. }\end{array}$ & \multicolumn{7}{|c|}{ Bargad dyed Khadi fabric } \\
\hline 1. & $\begin{array}{c}\text { Statistical } \\
\text { value point }\end{array}$ & Texture & Colour & Appearance & Brightness & Smoothness & Overall \\
\hline 2. & Total Marks & 786 & 754 & 761 & 472 & 790 & 3,563 \\
\hline 3. & Average & 9.82 & 9.42 & 9.51 & 5.9 & 9.87 & 44.53 \\
\hline 4. & Percentage & 98.25 & 94.25 & 95.12 & 59 & 98.75 & 89.07 \\
\hline 5. & Mean & \multicolumn{7}{|c|}{712.6} \\
\hline 6. & S.D. & \multicolumn{7}{c|}{0.79 .39} \\
\hline 7. & 't' & \multicolumn{7}{c|}{4} \\
\hline 8. & df & \multicolumn{7}{c|}{40.05} \\
\hline 9. & p & \multicolumn{7}{|c|}{} \\
\hline
\end{tabular}

Above table explain that Bargad dyed Khadi fabric got good marks in smoothness aspect comparison of others as aspect and ' $\mathrm{t}$ ' value are significant at $5 \%(\mathrm{p}<0.05)$ level.

\section{Visual evaluation of Khadi fabric dyed with Jamun antibacterial and antifungal natural dye}

\begin{tabular}{|c|c|c|c|c|c|c|c|}
\hline $\begin{array}{l}\text { Sr. } \\
\text { no. }\end{array}$ & \multicolumn{7}{|c|}{ Jamun dyed Khadi fabric } \\
\hline 1. & $\begin{array}{c}\text { Statistical } \\
\text { value point }\end{array}$ & Texture & Colour & Appearance & Brightness & Smoothness & Overall \\
\hline 2. & Total Marks & 795 & 702.5 & 684 & 458 & 768 & $3,407.5$ \\
\hline 3. & Average & 9.93 & 8.78 & 8.55 & 5.72 & 9.6 & 42.59 \\
\hline 4. & Percentage & 99.3 & 87.8 & 85.5 & 57.25 & 96 & 85.18 \\
\hline 5. & Mean & \multicolumn{6}{|c|}{681.5} \\
\hline 6. & S.D. & \multicolumn{6}{|c|}{133.007} \\
\hline 7. & ' $\mathrm{t}$ ' & \multicolumn{6}{|c|}{1.43} \\
\hline 8. & df & \multicolumn{6}{|c|}{4} \\
\hline 9. & $\mathrm{p}$ & \multicolumn{6}{|c|}{$<0.05$} \\
\hline
\end{tabular}

Above table explain that Jamun dyed Khadi fabric got good marks in texture aspect comparison of others as aspect and ' $\mathrm{t}$ ' value are significant at $5 \%(\mathrm{p}<0.05)$ level. 
VISUAL EVALUATION OF KHADI FABRIC DYED WITH ANTIBACTERIAL AND ANTIFUNGAL NATURAL DYE

DeepaTyagi, Pankaj Chhabra

Visual evaluation of Khadi fabric dyed with Shisham antibacterial and antifungal natural dye

\begin{tabular}{|c|c|c|c|c|c|c|c|}
\hline $\begin{array}{c}\text { Sr. } \\
\text { no. }\end{array}$ & \multicolumn{7}{|c|}{ Shisham dyed Khadi fabric } \\
\hline 1. & $\begin{array}{c}\text { Statistical } \\
\text { value point }\end{array}$ & Texture & Colour & Appearance & Brightness & Smoothness & Overall \\
\hline 2. & Total Marks & 797 & 711 & 706 & 452 & 736 & 3,402 \\
\hline 3. & Average & 9.96 & 8.88 & 8.82 & 5.65 & 9.2 & 42.51 \\
\hline 4. & Percentage & 99.6 & 88.8 & 88.2 & 56.5 & 92 & 85.05 \\
\hline 5. & Mean & \multicolumn{7}{|c|}{680.4} & 131.89 \\
\hline 6. & S.D. & \multicolumn{7}{|c|}{0.43} \\
\hline 7. & 't' & \multicolumn{7}{|c|}{4} \\
\hline 8. & df & \multicolumn{7}{|c|}{$<05$} \\
\hline 9. & p & \multicolumn{7}{|c|}{} \\
\hline
\end{tabular}

Above table explain that Shisham dyed Khadi fabric got good marks in texture aspect comparison of others as aspect and ' $\mathrm{t}$ ' value are significant at $5 \%(\mathrm{p}<0.05)$ level.

Visual evaluation of Khadi fabric dyed with Mehndi antibacterial and antifungal natural dye

691.4

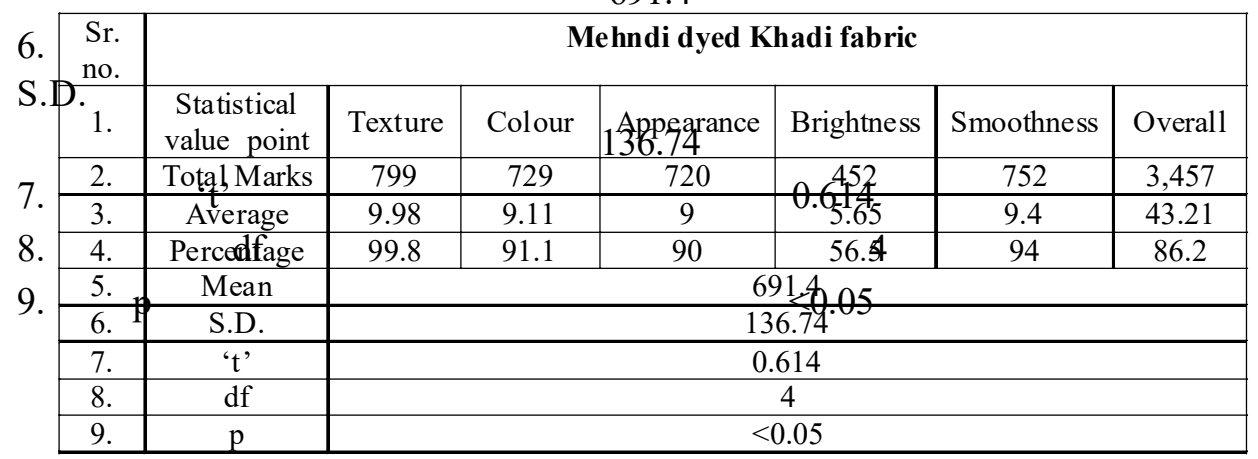

Above table explain that Mehndi dyed Khadi fabric got good marks in texture aspect comparison of others as aspect and ' $\mathrm{t}$ ' value are significant at $5 \%(\mathrm{p}<0.05)$ level. 
RJPSSs, Vol. XLVI No.1, June 2020 ISSN: (P)0048-7325 (e) 2454-7026 Impact Factor 7.821 (SJIF)

https://doi.org/10.31995/rjpsss.2020v46i01.11

Visual evaluation of Khadi fabric dyed with Guava antibacterial and antifungal natural dye

\begin{tabular}{|c|c|c|c|c|c|c|c|}
\hline Sr. & \multicolumn{7}{|c|}{ Guava dyed Khadi fabric } \\
\hline 1. & $\begin{array}{c}\text { Statistical } \\
\text { value point }\end{array}$ & Texture & Colour & Appearance & Brightness & Smoothness & Overall \\
\hline 2. & Total Marks & 795 & 729 & 706 & 460 & 747 & 3,437 \\
\hline 3. & Average & 9.93 & 9.11 & 8.82 & 5.75 & 9.33 & 42.96 \\
\hline 4. & Percentage & 99.3 & 91.1 & 88.2 & 57.5 & 93.3 & 85.92 \\
\hline 5. & Mean & \multicolumn{6}{|c|}{687.4} \\
\hline 6. & S.D. & \multicolumn{6}{|c|}{131.26} \\
\hline 7. & ' $\mathrm{t}$ ' & \multicolumn{6}{|c|}{1.01} \\
\hline 8. & $\mathrm{df}$ & \multicolumn{6}{|c|}{4} \\
\hline 9. & $p$ & \multicolumn{6}{|c|}{$<0.05$} \\
\hline
\end{tabular}

Above table explain that Guava dyed Khadi fabric got good marks in texture aspect comparison of others as aspect and ' $\mathrm{t}$ ' value are significant at $5 \%(\mathrm{p}<0.05)$ level.

\section{Visual evaluation of Khadi fabric dyed with Ashok antibacterial and antifungal natural dye}

\begin{tabular}{|c|c|c|c|c|c|c|c|}
\hline $\begin{array}{l}\text { Sr. } \\
\text { no. }\end{array}$ & \multicolumn{7}{|c|}{ Ashok dyed Khadi fabric } \\
\hline 1. & $\begin{array}{c}\text { Statistical } \\
\text { value point }\end{array}$ & Texture & Colour & Appearance & Brightness & Smoothness & Overall \\
\hline 2. & Total Marks & 797 & 727 & 733 & 442 & 742 & 3,441 \\
\hline 3. & Average & 9.96 & 9.08 & 9.16 & 5.52 & 9.27 & 43.01 \\
\hline 4. & Percentage & 99.6 & 90.8 & 91.6 & 55.2 & 92.7 & 85.9 \\
\hline 5. & Mean & \multicolumn{6}{|c|}{688.2} \\
\hline 6. & S.D. & \multicolumn{6}{|c|}{139.83} \\
\hline 7. & 't & \multicolumn{6}{|c|}{0.71} \\
\hline 8. & df & \multicolumn{6}{|c|}{4} \\
\hline 9. & $\mathrm{p}$ & \multicolumn{6}{|c|}{$<0.05$} \\
\hline
\end{tabular}

Above table explain that Ashok dyed Khadi fabric got good marks in texture aspect comparison of others as aspect and ' $\mathrm{t}$ ' value are significant at $5 \%(\mathrm{p}<0.05)$ level.

It was found from the collected data that 640 customers were selected randomly for the assessment of the visual evaluation of naturally dyed Khadi fabric. We found that Bargad bark dye(44.53) got the overall highest average value for Khadi fabric dyed with antibacterial and antifungal natural dye. Mehndi leaves dye (9.98) got higher average value about the texture for Khadi for Khadi fabric dyed with antibacterial and antifungal natural dye. Bargad bark dye (9.42) angular 
VISUAL EVALUATION OF KHADI FABRIC DYED WITH ANTIBACTERIAL AND ANTIFUNGAL NATURAL DYE DeepaTyagi, Pankaj Chhabra

Bark dye (9.42) got higher average value about the color for Khadi for Khadi fabric dyed with antibacterial and antifungal natural dye. Gullar Bark dye (9.51) got higher average value about the appearance for Khadi for Khadi fabric dyed with antibacterial and antifungal natural dye. Guava Bark dye (5.75) got a higher average value about the brightness for Khadi for Khadi fabric dyed with antibacterial and antifungal natural dye. Bargad Bark dye (9.87) got a higher average value about the smoothness for Khadi for Khadi fabric dyed with antibacterial and antifungal natural dye. Further analysis of data from the above result reveals that mean value, S.D., 't', and df value of all dyed khadi sample are significant at 5\% $(\mathrm{p}<0.05)$ level.

\section{Conclusion}

Natural dyeing a preferred practice as a traditional method of coloring various materials and releasing the dyes obtained from various plants or animals. In this research, dyeing experiments were carried out using natural dyes on fabric. As a result of the research, it was seen that different dark and light colors were obtained from materials dyed with different natural dyes. Different natural dye has different antibacterial and antifungal activity. In this study it was observed in the dyeing experiment concluded that weld, from which light color tones are obtained, had the best value in terms of different fastness tests. It was conducted that the dyes gave the best results. There was a good visual evaluation. It can see that level of visual evaluation of dyes in different aspects showed significant results.

\section{References}

1. Offer G. Oby, E.A. Nzekwe, Grace Nwagboso "Extraction and harnessing natural dye for fabric dyeing techniques in Industries in South-East and West Nigeria" International journal of scientific and research publication, Volume 9, issue 6, June 2019

2. Manipal G. Renaldo, “Dyeing fabrics using Indigenous materials" International Journal of Innovative technology and exploring engineering, Volume 8, issue 6, April 2019

3. S. Saxena and A.S.M. Raja, "Natural dyes, source, Chemistry, application and sustainability issue, Central Institute for Research on Cotton Technology, Mumbai, India

4. Ahlström L, Eskilsson CS, Björklund E, Determination of banned azo dyes in consumer goods, Trends in Analytical Chemistry, 24(1), 2005, 49-56. 5.

5. Jha CK, Kumar R, Kumar SV, Rajeswari VD, Extraction of natural dye from the marigold flower (Tageteserectal.) and dyeing of fabric and 
RJPSSs, Vol. XLVI No.1, June 2020 ISSN: (P)0048-7325 (e) 2454-7026 Impact Factor 7.821 (SJIF)

https://doi.org/10.31995/rjpsss.2020v46i01.11

yarns: A focus on colorimetric analysis and fastness properties, Der Pharmacia Lettre, 7(1), 2015, 185-195.

6. Bechtold SA, Chatterjee ST, Chatterjee $\mathrm{CH}$, Guha AK, Adsorptive removal of congo red, a carcinogenic textile dye by chitosan hydro beads: Binding mechanism, equilibrium and kinetics, Colloids and Surfaces A: Physicochemical and Engineering Aspects, 299(2), 2007, 146-152.

7. Cristea GY, Vilarem SJ, Ultrasound-assisted enhancement in natural dye extraction from beetroot for industrial applications and natural dyeing of leather, Ultrasonics Sonochemistry, 16(6), 2003, 782-789. 11.

8. Ghorpade B, Darvekar M, Vankar PS, Ecofriendly cotton dyeing with Sappan wood dye using ultrasound energy, Colourage, 2000, 27-30. 